\title{
Analisis Kandungan Bakteri Fecal Coliform pada Sungai Kuin Kota Banjarmasin
}

\author{
Deasy Arisanty ${ }^{1}$, Sidharta Adyatma ${ }^{1}$, dan Nurul Huda ${ }^{1}$
}

Program Studi Pendidikan Geografi, FKIP, Universitas Lambung Mangkurat, Banjarmasin,

Kalimantan Selatan, Indonesia

Email: deasyarisanty@unlam.ac.id

Diterima : Juli 2017 ; Direvisi : Agustus 2017; Dipubikasikan: September 2017

(c) 2017 Fakultas Geografi UGM dan Ikatan Geograf Indonesia.

\begin{abstract}
Abstrak Sungai Kuin merupakan anak Sungai Martapura yang yang bermuara di Sungai Barito. Sungai ini terdapat di Kota Banjarmasin, Kalimantan Selatan. Kejadian diare tertinggi di Kota Banjarmasin terjadi di bantaran Sungai Kuin, sehingga perlu dilakukan penelitian mengenai kandungan bakteri fecal coliform pada sungai ini. Penelitian ini bertujuan menganalisis jumlah kandungan bakteri fecal coliform di Sungai Kuin dan menganalisis cara mengatasi penurunan kualitas air Sungai Kuin akibat keberadaan bakteri fecal coliform. Data diambil sepanjang Sungai Kuin dengan panjang 3.909,00 m yang terbagi menjadi 20 segmen (10 segmen berada di bagian kanan sungai dan 10 segmen berada di bagian kiri sungai). Pembagian segmen berdasarkan panjang sungai per 390 meter, dengan sampel sebanyak 5 segmen yang mewakili segmen lainnya. Teknik analisis yang digunakan yaitu dengan menggunakan hasil uji laboratorium, perbandingan terhadap Peraturan Gubernur Kalimantan Selatan No 5 tahun 2007 dan referensi dari katalog informasi pilihan jamban sehat. Hasil penelitian menunjukkan bahwa kualitas air Sungai Kuin adalah berwarna kecoklatan, dan terkadang tercium bau terutama pada saat hujan turun. Jumlah rerata kandungan bakteri fecal coliform di Sungai Kuin adalah 210/100 ml pada saat pasang naik dan 780/100 ml pada saat pasang surut. Kualitas air Sungai Kuin tidak tidak memenuhi baku mutu air minum karena kandungan bakteri fecal coliform berada di atas baku mutu 100/100 ml. Penurunan kualitas air Sungai Kuin dapat dilakukan dengan pembangunan jamban yang sesuai dengan lingkungan perairan pasang surut.
\end{abstract}

Kata Kunci: Bakteri, Fecal Coliform, Kualitas Air, Sungai

Abstract Kuin River is a tributary of Martapura River, which flows into Barito River. It traverses Banjarmasin City, South Kalimantan Province. The highest diarrhea incidence in this city was found in the banks of Kuin River. Therefore, this research, focusing on fecal coliform bacteria in Kuin River, becomes necessary. Aside from analyzing the concentration of fecal coliform, it aimed to determine the strategies for dealing with the resultant water quality deterioration. The research data was obtained directly from Kuin River, i.e., $3.909 \mathrm{~m}$ in length. The river was divided into 20 segments (10 segments on each side of the river); hence, the length of each segment was $390 \mathrm{~m}$. Afterwards, five segments were selected to represent the river. The research used laboratory analysis and, then, compared the analysis results with the Governor Regulation No. 5/2007 and other references, i.e., selected catalogs containing information of healthy lavatories. The results showed that the physical appearance of Kuin River included brownish color and foul-smelling water, especially during rainfall. The average concentration of fecal coliform bacteria in Kuin River was 210/100 ml during high tides and $780 / 100 \mathrm{ml}$ during low tides. The water quality did not meet the standard for drinking water because the bacteria found in the river was above the allowed concentration, i.e., 100/100 ml. Water quality deterioration can be decelerated by constructing lavatories that are suitable for tidal environment.

Keywords: Bacteria, Fecal Coliform, Water Quality, River

\section{PENDAHULUAN}

Air merupakan kebutuhan dasar hidup di bumi yang menentukan kesehatan dan kesejahteraan manusia (Cahyadi et al., 2011; Sumantri, 2013). Salah satu sumber air tawar dengan potensi yang besar adalah sungai. Sungai menyediakan air tawar yang dapat digunakan untuk memenuhi kebutuhan rumah tangga (Notoatmodjo, 2007). Menurut Peraturan Pemerintah Nomor 38 Tahun 2011 tentang sungai, sungai merupakan wadah air alami sebagai penyedia air dan wadah air untuk memenuhi kebutuhan rumah tangga, sanitasi lingkungan, pertanian, industri, pariwisata, olahraga, pertahanan, perikanan, pembangkit tenaga listrik dan transportasi.
Sungai banyak dijadikan sebagai tempat pembuangan kotoran dan sampah terutama pada kota-kota besar (Indarsih dkk., 2011; Shoolikhah dkk., 2014). Terdapat keterkaitan antara penggunaan lahan dengan konsentrasi bakteri pada sungai (Eleria and Vogel, 2005). Urbanisasi dan industrialisasi sangat berpengaruh terhadap keberadaan bakteri fecal coliform pada perairan (Kalaivani, et.al, 20014). Fecal coliform akan meningkat pada wilayah sungai perkotaan seiring dengan bertambahnya aliran sungai dan curah hujan (Sanders et.al, 2013).

Masyarakat mendirikan jamban di sungai yang menyebabkan sungai tercemar kotoran manusia. 
Kotoran manusia dapat menjadi sumber penyakit (Notoatmodjo, 2007). Wilayah dengan septic tank yang banyak merupakan penghasil bakteri fecal coliform yang tinggi (Eukene et.al, 2014). Keterdapatan bakteri pada tubuh perairan menjadi indikator kualitas air permukaan dan kesesuaian air tersebut untuk dimanfaatkan sebagai air minum, rekreasi, irigasi, dan perikanan (Onwumere, 2007; Haider and Ali, 2011).

Kotoran manusia dapat menghasilkan bakteri pathogen berupa Escherichia coli, Shigella sp., Vibrio cholerae, Campylobacter jejuni dan Salmonella merupakan anggota dari fecal coliform. Bakteri ini dapat menyebabkan terjadinya diare pada manusia. Escherechia coli apabila dikonsumsi terus-menerus dalam jangka panjang akan berdampak pada timbulnya penyakit seperti radang usus, diare, infeksi pada saluran kemih dan saluran empedu (Prayitno, 2009). Diare adalah suatu kondisi dimana seseorang buang air besar dengan konsistensi lembek atau cair, bahkan dapat berupa air saja dan frekuensinya lebih sering (biasanya tiga kali atau lebih) dalam satu hari (Kementerian Kesehatan Republik Indonesia, 2011).

Kota Banjarmasin yang disebut sebagai kota seribu sungai merupakan kota yang dilewati oleh banyak sungai. Sungai dimanfaatkan oleh masyarakat untuk berbagai macam aktivitas termasuk dimanfaatkan sebagai jamban (Tabel 1). Banyaknya jamban yang didirikan disepanjang sungai di Kota Banjarmasin telah menyebabkan terjadinya kasus diare yang cukup tinggi yaitu 11.623 kasus pada tahun 2014 (Dinas Kesehatan Kota Banjarmasin, 2015). Kejadian diare tertinggi ada di bantaran Sungai Kuin dengan total kasus pada puskesmas yang melayani wilayah di sekitar Sungai Kuin sebanyak 2.147 kasus (Tabel 2).

Tabel 1. Jamban dipinggiran Sungai Kuin per Kelurahan

\begin{tabular}{lcc}
\hline \multicolumn{1}{c}{ Kelurahan } & Jumlah Jamban (buah) & Jumlah Rumah di Pinggiran Sungai (buah) \\
\hline Kuin Cerucuk & 55 & 162 \\
Kuin Selatan & 36 & 140 \\
Kuin Utara & 109 & 181 \\
Pangeran & 67 & 100 \\
Antasan Kecil Timur & 26 & 46 \\
Pasar Lama & 7 & 51 \\
\multicolumn{1}{c}{ Total } & 300 & 680 \\
\hline
\end{tabular}

Sumber :Diolah dari Dinas Kesehatan Kota Banjarmasin (2015)

Tabel 2. Kasus Diare Setiap Sungai di Kota Banjarmasin Tahun 2014

\begin{tabular}{|c|c|c|c|c|}
\hline Sungai & Panjang (m) & Puskesmas & Kasus Diare (kasus) & Total (kasus) \\
\hline \multirow{4}{*}{ Kuin } & \multirow{4}{*}{3.909} & Kayu tangi & 278 & \multirow{4}{*}{2.147} \\
\hline & & Alalak Selatan & 536 & \\
\hline & & Kuin Raya & 940 & \\
\hline & & S.Parman & 393 & \\
\hline Jingah & 1.578 & Sei. Jingah & 699 & 699 \\
\hline Bilu & 530 & Cempaka Putih & 424 & 424 \\
\hline Kelayan & 3227 & Kelayan Dalam & 379 & 379 \\
\hline \multirow{2}{*}{ Pekapuran } & \multirow{2}{*}{1534} & Gadang Hanyar & 455 & \multirow{2}{*}{882} \\
\hline & & Pekapuran Raya & 427 & \\
\hline Gardu & 709 & Terminal & 297 & 297 \\
\hline Pengambangan & 1165 & 9 November & 276 & 276 \\
\hline Gg. Saadah & 473 & Teluk Tiram & 178 & 178 \\
\hline Palambuan & 1509 & Palambuan & 653 & 653 \\
\hline Banyiur & 1554 & Basirih Baru & 364 & 364 \\
\hline Teluk Dalam & 3428 & Teluk Dalam & 385 & 385 \\
\hline
\end{tabular}

Sumber : Diolah dari Dinas Kesehatan Kota Banjarmasin (2015) 
Angka kejadian diare mengalami peningkatan pada puncak musim kemarau. Namun demikian, pada musim hujan angka kejadian diare tetap ada karena air sungai tetap dimanfaatkan oleh masyarakat meskipun sebagian kebutuhan dicukupi dengan air hujan. Faktor lingkungan dominan yang menyebabkan terjadinya wabah diare, yaitu ketersediaan sarana air bersih yang tidak memadai dan pembuangan tinja dan limbah di sungai, sehingga terjadi pencemaran bakteri fecal coliform pada air sungai dan menimbulkan kejadian diare.

\section{METODE PENELITIAN}

Penelitian ini dilaksanakan pada Sungai Kuin dengan panjang $3.909,00 \mathrm{~m}$ yang terbagi menjadi 20 segmen (10 segmen berada di bagian kanan sungai dan 10 segmen berada di bagian kiri sungai) pembagian segmen berdasarkan panjang sungai per 390 meter kemudian dilakukan penghitungan jumlah jamban di setiap segmen (Tabel 3). Sampel dalam penelitian ini menggunakan teknik cluster sampling berdasarkan pada kepadatan jamban cemplung di pinggiran sungai sebagai dasar pengambilan sampel.

Tahap pertama yang dilakukan untuk menentukan sampel adalah membagi kepadatan jumlah jamban menjadi beberapa kelas yang disajikan pada Tabel 4. Tahap kedua yakni, setiap satu segmen diambil secara acak untuk mewakili setiap kelas sampel yang akan menjadi lokasi pengambilan sampel untuk lebih jelasnya disajikan pada Tabel 5. Tahap terakhir adalah menentukan titik pengambilan sampel air Sungai Kuin dibelakang rumah warga secara acak.

Tabel 3. Jumlah Jamban di Sungai Kuin

\begin{tabular}{ccc}
\hline Segmen & Jumlah Jamban (buah) & Jumlah Rumah (buah) \\
\hline I A & 17 & 39 \\
I B & 11 & 35 \\
II A & 18 & 36 \\
II B & 14 & 40 \\
III A & 23 & 40 \\
III B & 18 & 37 \\
IV A & 30 & 37 \\
IV B & 12 & 50 \\
V A & 21 & 29 \\
V B & 14 & 46 \\
VI A & 23 & 38 \\
VI B & 8 & 45 \\
VII A & 27 & 29 \\
VII B & 9 & 23 \\
VIII A & 17 & 33 \\
VIII B & 7 & 26 \\
IX A & 14 & 26 \\
IX B & 1 & 18 \\
X A & 12 & 20 \\
X B & 6 & 33 \\
\hline Puk & & 36 \\
\hline
\end{tabular}

Sumber : Pengukuran Lapangan (2015)

Tabel 4. Kelas Kepadatan Jamban di Lokasi Kajian

\begin{tabular}{lll}
\hline \multicolumn{1}{c}{ Jumlah Jamban Cemplung } & \multicolumn{1}{c}{ Kelas Kepadatan } & \multicolumn{1}{c}{ Segmen } \\
\hline $1-6$ & Sangat jarang & IX B dan XB \\
$7-12$ & Jarang & I B, IV B, VI B, VII B, VIII B dan X A \\
$13-18$ & Sedang & I A, II A, II B, III B, V B, VIII A, dan IX A \\
$19-24$ & Padat & III A, V A, dan VI A \\
$25-30$ & Sangat Padat & IV A dan VII A \\
\hline
\end{tabular}

Sumber : Pengukuran Lapangan (2015) 
Tabel 5. Sampel Penelitian

\begin{tabular}{ccc}
\hline Segmen & Jumlah jamban dipinggiran sungai (buah) & Jumlah Rumah (buah) \\
\hline IX B & 1 & 18 \\
VIII B & 7 & 26 \\
II A & 18 & 36 \\
VA & 21 & 29 \\
IV A & 30 & 37 \\
\hline
\end{tabular}

Sumber : Pengukuran Lapangan (2015)

Waktu pengambilan sampel dilakukan pada puncak musim hujan pada saat pasang naik tertinggi dan pasang surut terendah. Pengambilan sampel dilakukan pada tanggal 12 Januari 2016 dengan ketinggian pasang surut $-0,1 \mathrm{~m}$ pada pukul 11.20 WITA dan ketinggian pasang naik 2,3 m pada pukul 20.00 WITA (Central Indonesia, 2015). Sampel air kemudian dianalisis di laboratorium untuk mendapatkan hasil kandungan bakteri Fecal Coliform.

Selain pengukuran bakteri, dilakukan juga pengukuran kualitas fisik air sungai dengan menggunakan EC meter. Parameter yang diukur adalah suhu, daya hantar listrik (DHL), Natrium Klorida $(\mathrm{NaCl})$ dan Total Dissolved Solids (TDS). Selain itu dilakukan pengamatan rasa, bau, dan warna air sungai. Selain itu, dilakukan penentuan persepsi masyarakat yang menggunakan air sungai dengan menggunakan kuesioner. Analisis persepsi masyarakat adalah dengan menggunakan analisis persentase.

\section{HASIL DAN PEMBAHASAN}

\section{Kualitas Fisik air sungai}

Kualitas fisik air sungai yang dianalisis dalam penelitian ini meliputi rasa, suhu, DHL, $\mathrm{NaCl}$, TDS, warna dan bau. Kualitas fisik air sungai disajikan pada Tabel 6. Hasil analisis berdasarkan persepsi masyarakat terdapat pada Tabel 7.

Tabel 6. Kualitas Fisik Air Sungai Kuin

\begin{tabular}{|c|c|c|c|c|c|c|c|}
\hline Segmen & Rasa & $\begin{array}{c}\text { Suhu } \\
{ }^{\circ} \mathrm{C}\end{array}$ & $\begin{array}{c}\text { DHL } \\
\mu \mathrm{s}\end{array}$ & $\begin{array}{c}\text { Nacl } \\
\%\end{array}$ & $\begin{array}{l}\text { TDS } \\
\text { ppm }\end{array}$ & Warna & Bau \\
\hline IX B & $\begin{array}{c}\text { bergetah dan rasa } \\
\text { tanah }\end{array}$ & 29.2 & 62.6 & 0.4 & 31.6 & coklat & tidak berbau \\
\hline VIII B & $\begin{array}{l}\text { bergetah dan rasa } \\
\text { tanah }\end{array}$ & 29.3 & 65.5 & 0.4 & 32.6 & coklat & tidak berbau \\
\hline II A & tidak berasa & 29.9 & 75.8 & 0.4 & 37.9 & coklat & tidak berbau \\
\hline VA & $\begin{array}{l}\text { bergetah dan rasa } \\
\text { tanah }\end{array}$ & 29.4 & 84.2 & 0.5 & 41.8 & coklat & tidak berbau \\
\hline IV A (1) & $\begin{array}{l}\text { bergetah dan rasa } \\
\text { tanah }\end{array}$ & 20.7 & 83.6 & 0.4 & 41.9 & coklat & tidak berbau \\
\hline IVA (2) & $\begin{array}{c}\text { bergetah dan rasa } \\
\text { tanah }\end{array}$ & 29.9 & 70.8 & 0.4 & 35.4 & coklat & tidak berbau \\
\hline
\end{tabular}

Sumber: Hasil Pengukuran (2015) 
Tabel 7. Persepsi Masyarakat terhadap Kualitas Fisik Air Sungai Kuin

\begin{tabular}{ccccccc}
\hline \multirow{2}{*}{ Kriteria Jawaban } & \multicolumn{2}{c}{ Bau } & \multicolumn{2}{c}{ Warna } & \multicolumn{2}{c}{ Kekeruhan } \\
& $\mathrm{f}$ & $\%$ & $\mathrm{f}$ & $\%$ & $\mathrm{f}$ & 0 \\
\hline Tidak pernah & 5 & 25 & 0 & 0 & 0 & 0 \\
Jarang & 11 & 55 & 10 & 50 & 10 & 50 \\
Sering & 2 & 10 & 8 & 40 & 10 & 50 \\
Selalu & 2 & 10 & 2 & 10 & 0 & 0 \\
Jumlah & 20 & 100 & 20 & 100 & 20 & 100 \\
\hline
\end{tabular}

Sumber: Analisis Data (2015)

\section{Bau}

Sungai Kuin terkadang mengeluarkan bau pada saat-saat tertentu seperti setelah hujan. Hal ini karena mineral-mineral yang mengendap di dasar sungai naik ke permukaan sungai dan berbaur dengan air dan zat lain seperti limbah, sampah, kotoran, zat organik, dan anorganik. Namun demikian, sebanyak 55\% masyarakat menyatakan bahwa air Sungai Kuin jarang mengeluarkan bau. Bau air Sungai Kuin hanya tercium di daerah yang padat rumah penduduk seperti pada segmen IV A karena banyaknya jamban cemplung dan masyarakat yang membuang sampah langsung ke sungai. Sebaliknya, pada bagian muara Sungai Kuin tidak tercium bau sama sekali karena volume air yang banyak dan telah mengalami pengenceran.

\section{Warna}

Sungai Kuin terlihat tidak berwarna pada saat pasang naik. Namun demikian, Sungai Kuin lebih sering nampak berwarna kecoklatan bahkan sesekali berwarna kehijauan. Meskipun demikian, warna hijau tidak berlangsung lama karena keluar masuknya air dari hulu maupun Muara Sungai Kuin. Sungai Kuin berwarna kecoklatan karena banyaknya sampah organik yang dibuang masyarakat ke sungai tersebut.

\section{Kekeruhan}

Sungai Kuin memiliki kekeruhan yang tinggi. Warna keruh tersebut disebabkan air Sungai Kuin mengalami pencampuran antara air, tanah liat, lumpur, koloid tanah dan organisme perairan (mikroorganisme), tetapi saat memasuki wilayah muara sungai kekeruhan air mulai berkurang karena volume air yang meningkat.

\section{DHL (Daya Hantar Listrik) dan $\mathrm{NaCl}$}

Daya hantar listrik dan kandungan $\mathrm{NaCl}$ di wilayah penelitian termasuk pada kriteria rendah. Hal ini berarti bahwa air sungai termasuk dalam kriteria air tawar. Penelitian dilaksanakan pada musim penghujan, sehingga air hujan masuk ke sungai yang menyebabkan sungai menjadi tawar. Namun demikian, saat waktu musim kemarau, air laut dapat masuk ke Sungai Kuin yang menyebabkan air menjadi asin. Hal ini karena salinitas air sungai dapat terpengaruh oleh pasang surut air laut (Darmanto dan Cahyadi, 2013)

\section{TDS}

Nilai TDS terkait dengan kekeruhan air sungai. Nilai TDS yang tinggi menyatakan bahwa sedimen yang terlarut dan tingkat kekeruhan air yang tinggi. Nilai TDS di lokasi penelitian termasuk tinggi. Hal ini sesuai dengan kenampakan pada warna air sungai yang berwarna kecoklatan. Air sungai yang keruh dan berwarna kecoklatan tidak layak untuk dikonsumsi.

\section{Pemanfaatan Air Sungai}

Hasil analisis terhadap data wawancara yang dikumpulkan dalam penelitian ini menunjukkan bahwa pemanfaatan air Sungai Kuin adalah untuk sumber air minum, masak, sanitasi, mandi dan mencuci. Masingmasing memiliki tingkat penggunaan yang beragam. Data hasil wawancara tentang pemanfaatan air Sungai Kuin disajikan pada Tabel 8.

Tabel 8. Pemanfaatan Air Sungai Kuin

\begin{tabular}{cccccccccccc}
\hline \multirow{2}{*}{ Kriteria Jawaban } & \multicolumn{2}{c}{ Minum } & \multicolumn{2}{c}{ Masak } & \multicolumn{2}{c}{ Sanitasi } & \multicolumn{2}{c}{ Mandi } & \multicolumn{2}{c}{ Mencuci } \\
& $\mathrm{f}$ & $\%$ & $\mathrm{f}$ & $\%$ & $\mathrm{f}$ & $\%$ & $\mathrm{f}$ & $\%$ & $\mathrm{f}$ & $\%$ \\
\hline Selalu & 5 & 25 & 5 & 25 & 10 & 50 & 9 & 45 & 10 & 50 \\
Sering & 0 & 0 & 0 & 0 & 1 & 5 & 0 & 0 & 0 & 0 \\
Jarang & 0 & 0 & 0 & 0 & 3 & 15 & 3 & 15 & 4 & 20 \\
Tidak pernah & 15 & 75 & 15 & 75 & 6 & 30 & 8 & 40 & 6 & 30 \\
Jumlah & 20 & 100 & 20 & 100 & 20 & 100 & 20 & 100 & 20 & 100 \\
\hline
\end{tabular}

Sumber: Hasil Analisis Data (2015) 


\section{Minum}

Sebanyak 25\% masyarakat di sekitar Sungai Kuin masih memanfaatkan air Sungai Kuin untuk sumber air minum. Air sungai dimanfaatkan sebagai sumber air minum dengan cara air diendapkan dengan tawas selama beberapa hari kemudian di masak. Meskipun demikian, sebanyak 75\% masyarakat sudah memanfaatkan air PDAM ataupun membeli galon isi ulang. Hal ini menunjukkan bahwa masyarakat semakin sadar dengan kualitas Sungai Kuin yang dipersepsikan tidak layak untuk sumber air minum.

\section{Masak}

Sebanyak 25\% masyarakat di sekitar Sungai Kuin masih memanfaatkan air Sungai Kuin untuk keperluan memasak. Namun demikian sebanyak 75\% masyarakat sudah memanfaatkan air PDAM ataupun membeli air sulingan yang dijual di sekitar Sungai Kuin. Kondisi ini sesuai dengan hasil wawancara terkait dengan sumber air minum.

\section{Sanitasi}

Sebanyak 50\% masyarakat di sekitar Sungai Kuin memanfaatkan air Sungai Kuin untuk sanitasi dengan alasan menghemat air PDAM. Sebanyak 15\% masyarakat memanfaatkan air Sungai Kuin untuk sanitasi karena air PDAM tidak mengalir dengan lancar saat memasuki musim kemarau, sedangkan 30\% lainnya membeli air sulingan yang dijual masyarakat sekitar Sungai Kuin. Kondisi inilah yang semakin memperburuk kualitas air Sungai Kuin.

\section{Mandi}

Sebanyak 45\% masyarakat di sekitar Sungai Kuin memanfaatkan air Sungai Kuin untuk mandi dengan cara langsung menceburkan diri ke sungai karena dianggap lebih praktis. Sebanyak 15\% masyarakat memanfaatkan air Sungai Kuin untuk mandi hanya pada saat air pasang dan terlihat bersih, sedangkan $40 \%$ lainnya membeli air sulingan yang dijual masyarakat sekitar Sungai Kuin.

\section{Mencuci}

Sebanyak 50\% masyarakat di sekitar Sungai Kuin memanfaatkan air Sungai Kuin untuk mencuci dengan alasan menghemat air PDAM tetapi kemudian dilanjutkan dengan membilas cucian baik itu pakaian ataupun alat makan dengan air PDAM. Sebanyak 20\% masyarakat memanfaatkan air Sungai Kuin untuk mencuci hanya pada saat air pasang dan terlihat bersih, sedangkan 30\% lainnya membeli air sulingan yang dijual masyarakat sekitar Sungai Kuin.

Pemanfaatan air Sungai Kuin pada saat musim penghujan dan musim kemarau oleh masyarakat sekitar sungai kuin hanya pada kisaran $<40$ liter - 60 liter per hari (Tabel 9). Hal ini karena kebanyakan masyarakat memanfaatkan air sungai hanya untuk keperluan sanitasi. Hanya sebagian kecil masyarakat saja yang memanfaatkan air sungai untuk keperluan minum dan masak.

Tabel 9. Jumlah Air yang Diambil pada Saat Musim Penghujan dan Kemarau

\begin{tabular}{ccccc}
\hline Kriteria Jawaban & \multicolumn{2}{c}{ Musim Penghujan } & \multicolumn{2}{c}{ Musim Kemarau } \\
& $\mathrm{f}$ & $\%$ & $\mathrm{f}$ & 70 \\
\hline$<0$ liter - 60 liter & 9 & 45 & 14 & 10 \\
60 liter - 80 liter & 3 & 15 & 2 & 10 \\
80 liter-100 liter & 3 & 15 & 2 & 10 \\
$>100$ liter & 5 & 25 & 20 & 100 \\
\hline Jumlah & 20 & 100 & 2 & 0 \\
\hline
\end{tabular}

Sumber: Hasil Analisis Data (2015)

\section{Jumlah Kandungan Bakteri Fecal Coliform di Sungai Kuin}

Pengujian pada sampel air Sungai Kuin pada tanggal 12 Januari 2016 didapatkan rerata kandungan bakteri fecal coliform pada saat pasang naik sebanyak 210/100 ml dan pada saat pasang surut sebanyak 780/100 ml (Tabel 10). Kandungan bakteri pada saat surut lebih tinggi daripada saat musim penghujan disemua segmen. Kandungan bakteri fecal coliform paling tinggi pada saat pasang naik terdapat pada Segmen IV A (1) yaitu 350/100 ml, sedangkan paling rendah terdapat pada Segmen IV A (2) yaitu 50/100ml.
Kandungan bakteri fecal coliform paling tinggi pada saat pasang surut terdapat pada Segmen IX B, Segmen II A dan Segmen IV A (1) yaitu 900/100 ml, sedangkan paling rendah terdapat pada sedang segmen yang memiliki kandungan bakteri fecal coliform paling rendah pada Segmen VIII B dan IV A (2) yaitu 500/100 ml. Jumlah jamban mempengaruhi kandungan bakteri. Kepadatan jamban tinggi pada segmen VA dan IVA (1) menyebabkan kandungan bakteri fecal coliform yang tinggi juga. Selain itu, kandungan bakteri juga dipengaruhi oleh volume air. Saat volume air tinggi mempunyai kadar bakteri tidak sebesar pada saat 
volume air menurun. Khotimah (2013) menyatakan bahwa kandungan bakteri fecal coliform tinggi pada saat surut dibandingkan saat pasang. Hal ini sesuai dengan hasil penelitian ini yang menunjukkan pola yang sama.

Tabel 10. Jumlah Rerata Kandungan Bakteri Fecal Coliform di Sungai Kuin

\begin{tabular}{ccc}
\hline Segmen & Pasang Naik (per $100 \mathrm{ml})$ & Pasang Surut (per $100 \mathrm{ml})$ \\
\hline IX B & 280 & 900 \\
VIII B & 70 & 500 \\
II A & 220 & 900 \\
V A & 280 & 900 \\
IV A (1) & 350 & 900 \\
IV A (2) & 50 & 500 \\
Rata-rata & 210 & 780 \\
\hline
\end{tabular}

Sumber : UPTD Laboratorium Kesehatan Banjarmasin (2016)

Kualitas Air Sungai Kuin berdasarkan Jumlah

Bakteri Fecal Coliform dibandingkan dengan

Peraturan Gubernur Kalimantan Selatan No 5

Tahun 2007

Peraturan Gubernur Kalimantan Selatan Nomor 05 Tahun 2007 tentang Peruntukan dan Baku Mutu Air Sungai, dinyatakan bahwa pengujian parameter biologi dilakukan melalui pengukuran kadar fecal coliform air yang peruntukannya dapat digunakan untuk air baku air minum, dan atau peruntukan lain yang mempersyaratkan mutu air yang sama dengan kegunaannya. Pengujian sampel air Sungai Kuin menunjukan kualitas air Sungai Kuin yang disajikan pada Tabel 11 dan Tabel 12.

Table 11. Baku Mutu Air Sungai Kuin saat Pasang Naik Dibandingkan dengan Peraturan Gubernur Kalimantan Selatan Nomor 05 Tahun 2007

\begin{tabular}{cccccc}
\hline Segmen & $\begin{array}{c}\text { fecal coliform } \\
\text { per } 100 \mathrm{ml}\end{array}$ & $\begin{array}{c}\text { Air baku } \\
\text { air minum } \\
100 / 100 \mathrm{ml}\end{array}$ & $\begin{array}{c}\text { Prasarana/sarana } \\
\text { rekreasi air } \\
1000 / 100 \mathrm{ml}\end{array}$ & $\begin{array}{c}\text { Pembudidayaan ikan } \\
\text { air tawar 2000/100 ml }\end{array}$ & $\begin{array}{c}\text { mengairi } \\
\text { pertanaman } \\
2000 / 100 \mathrm{ml}\end{array}$ \\
\hline IX B & 280 & & & & \\
VIII B & 70 & & & \\
II A & 220 & & & \\
V A & 280 & & & \\
IV A (1) & 350 & & \\
IV A (2) & 50 & & \\
Rata-rata & 210 & &
\end{tabular}

Sumber : UPTD Laboratorium Kesehatan Banjarmasin, 2016.

Keterangan :

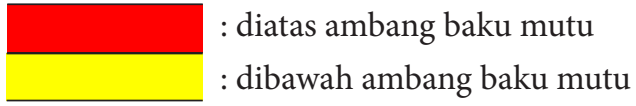

Tabel 12. Baku Mutu Air Sungai Kuin saat Pasang Surut Dibandingkan dengan Peraturan Gubernur Kalimantan Selatan Nomor 05 Tahun 2007

\begin{tabular}{lrrrrr}
\hline Segmen & $\begin{array}{c}\text { fecal coliform } \\
\text { per } 100 \mathrm{ml}\end{array}$ & $\begin{array}{c}\text { Air baku } \\
\text { air minum } \\
100 / 100 \mathrm{ml}\end{array}$ & $\begin{array}{c}\text { Prasarana/sarana } \\
\text { rekreasi air } \\
1000 / 100 \mathrm{ml}\end{array}$ & $\begin{array}{c}\text { Pembudidayaan ikan air } \\
\text { tawar 2000/100 ml }\end{array}$ & $\begin{array}{c}\text { mengairi } \\
\text { pertanaman } \\
2000 / 100 \mathrm{ml}\end{array}$ \\
\hline IX B & 900 & & & & \\
VIII B & 500 & & & \\
II A & 900 & & & \\
V A & 900 & & & \\
IV A (1) & 900 & & & \\
IV A (2) & 500 & & & \\
Rata-rata & 780 & &
\end{tabular}

Sumber : UPTD Laboratorium Kesehatan Banjarmasin, 2016. 
Keterangan :

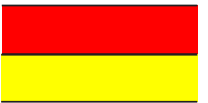

: diatas ambang baku mutu

: dibawah ambang baku mutu

Pengujian sampel air Sungai Kuin pada saat pasang naik menunjukan hasil untuk pemanfaatan sebagai air baku air minum hanya ada dua segmen yang kandungan bakteri fecal coliform di bawah ambang baku mutu yaitu segmen VIII B dan segmen IV A (2), sedangkan segmen lainnya berada di atas ambang baku mutu. Namun demikian, jika air sungai akan digunakan untuk pemanfaatan sebagai prasarana/ sarana rekreasi air, pembudidayaan ikan air tawar dan mengairi pertanaman, maka semua segmen berada di bawah ambang baku mutu. Hal ini karena baku mutu untuk air minum memiliki syarat yang paling tinggi (membutuhkan kualitas air yang paling baik). Pengujian sampel air Sungai Kuin pada saat pasang surut menunjukan hasil untuk pemanfaatan sebagai air baku air minum semua segmen berada diatas ambang baku mutu, sedangkan untuk pemanfaatan sebagai prasarana/sarana rekreasi air, pembudidayaan ikan air tawar dan mengairi pertanaman semua segmen berada dibawah ambang baku mutu.

\section{Cara Mengatasi Penurunan Kualitas Air Sungai Kuin akibat Keberadaan Bakteri Fecal Coliform}

Kontaminasi tinja di Sungai Kuin dapat dikurangi dengan membuat jamban yang sesuai dengan keadaan lingkungan perairan pasang surut (Gambar 2). Water and Sanitation Program (2009) memaparkan pembuatan jamban untuk perairan pasang surut adalah sumur penampung tinja yang dibangun di atas tanah. Sumur dihubungkan dengan slab dan kloset melalui sejumlah ring beton dan pipa. Banyaknya ring beton dan panjangnya pipa disesuaikan dengan ketinggian air. Jamban di daerah pasang naik dan pasang surut lebih mahal daripada jamban jenis lain. Selain itu, bahan bangunan dapat berkurang kekuatannya akibat terendam air. Oleh karena itu, diperlukan bahan yang tahan air.

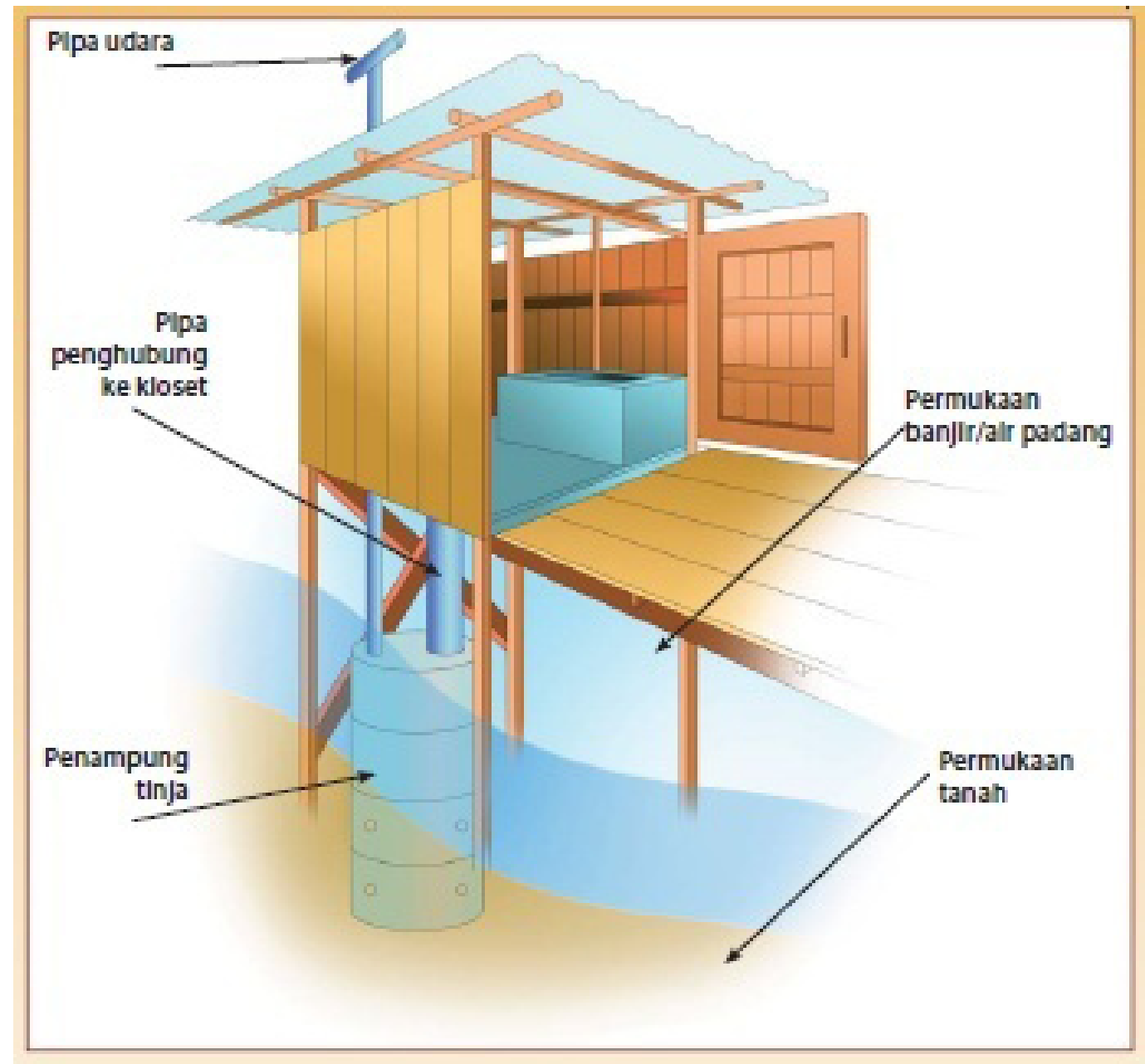

Gambar 2. Model Jamban untuk Lingkungan Perairan Pasang Surut

(Water and Sanitation Program, 2009) 
Pembangunan 1 jamban dengan model perairan pasang surut membutuhkan biaya sekitar $\mathrm{Rp} 4.373 .625$,Apabila setiap rumah tidakbisa memiliki 1 jamban, maka dapat dibangun jamban umum yang dapat menampung 5 sampai 6 kepala keluarga. Hal ini kemudian akan menyebabkan biaya dapat dibagi dan masing-masing kepala keluarga diperkirakan harus mengeluarkan biaya sekitar Rp 728.937,-. Kanan dan kiri Sungai Kuin terdapat 680 rumah yang terbagi dalam 20 segmen. Berdasarkan hal tersebut dibuat saran pembangunan jamban seperti pada Tabel 13. Pengelolaan limbah tinja dari jamban ini dapat dialirkan ke PD PAL, sehingga dapat dikelola dan airnya dikembalikan lagi ke Sungai Kuin dalam keadaan yang sudah aman.

Tabel 13. Jamban Umum di Sungai Kuin yang disarankan.

\begin{tabular}{ccc}
\hline Segmen & Jumlah Rumah (buah) & Jumlah Jamban yang Disarankan (buah) \\
\hline I A & 39 & 7 \\
I B & 35 & 6 \\
II A & 36 & 6 \\
II B & 40 & 7 \\
III A & 40 & 7 \\
III B & 37 & 6 \\
IV A & 37 & 6 \\
IV B & 50 & 8 \\
V A & 29 & 5 \\
V B & 46 & 8 \\
VI A & 38 & 6 \\
VI B & 45 & 8 \\
VII A & 29 & 5 \\
VII B & 23 & 3 \\
VIII A & 33 & 6 \\
VIII B & 26 & 4 \\
IX A & 26 & 4 \\
IX B & 18 & 3 \\
X A & 20 & 3 \\
X B & 33 & 6 \\
Hall Ant Da & &
\end{tabular}

Sumber : Hasil Analisis Data (2016)

\section{KESIMPULAN}

Kualitas fisik Sungai Kuin termasuk kurang baik karena nilai TDS yang tinggi dan warna sungai yang berwarna coklat karena kekeruhan yang tinggi. Sungai masih dimanfaatkan oleh masyarakat untuk kehidupan sehari-hari terutama untuk keperluan sanitasi. Sungai Kuin dengan jumlah jamban yang tinggi ternyata memiliki rata-rata kandungan bakteri fecal coliform pada saat pasang naik sebanyak $210 / 100 \mathrm{ml}$ dan pada saat pasang surut sebanyak 780/100 ml. Kualitas air Sungai Kuin berada di atas baku mutu untuk air minum, sehingga tidak layak untuk sumber air minum. Namun demikian, air Sungai Kuin masih layak untuk digunakan untuk prasarana/sarana rekreasi air, pembudidayaan ikan air tawar, peternakan dan mengairi pertanaman.
Cara untuk mengatasi penurunan kualitas air Sungai Kuin akibat keberadaan bakteri fecal coliform dapat dilakukan dengan membuat jamban khusus untuk daerah pasang surut.

\section{UCAPAN TERIMAKASIH}

Penelitian ini dibiayai oleh Fakultas Keguruan dan Ilmu Pendidikan (FKIP) Universitas Lambung Mangkurat. Peneliti mengucapkan terimakasih kepada Dekan FKIP, Universitas Lambung Mangkurat atas kepercayaannya dalam memberikan ijin dan pendanaan terhadap penelitian ini. Penulis juga mengucapkan terima kasih kepada asisten tim lapangan yang telah membantu dalam pengumpulan data yang digunakan dalam penelitian ini. 


\section{DAFTAR PUSTAKA}

Cahyadi, A., Priadmodjo, A. \& Yananto, A. (2011). Criticizing The Conventional Paradigm of Urban Drainage. Proceeding The $3 \mathrm{rd}$ International Graduated Student Conference on Indonesia. Yogyakarta: Sekolah Pascasarjana Universitas Gadjah Mada.

Central Indonesia. (2015). Pasang Surut Laut Sungai Barito. (Online). (http://www.pasanglaut.com/as/ central-indonesia/sungai-barito-borneo diakses 16 November 2015).

Darmanto, D. \& Cahyadi, A. (2013). Kajian Intrusi Air Laut Melalui Sungai di Pesisir Kabupaten Demak Jawa Tengah. Majalah Geografi Indonesia, 27(1), $1-10$.

Dinas Kesehatan Kota Banjarmasin. (2015). Distribusi Penderita Diare menurut Golongan Umur Kota Banjarmasin. Laporan Penelitian. Banjarmasin: Dinas Kesehatan Kota Banjarmasin, Kalimantan Selatan.

Dinas Sumber Daya Air dan Drainase. (2014). Peta Skematik Sungai Kota Banjarmasin. Banjarmasin: Dinas Sumber Daya Air dan Drainase Kota Banjarmasin, Kalimantan Selatan.

Eleria, A. \& Vogel, W.M. (2005). Predicting Fecal Coliform Bacteria Levels in the Charles River, Massachusetts, USA. Journal of the American Water Resources Association (JAWRA), 41(5), 1195-1209.

Eukene, O., Flores, M.J.L. \& Maglangit, F.F. (2014). Water Quality Asessment of Bulacao River, Cebu, Philipphines Using Fecal and Total Coliform as Indicator. Journal of Biodiversity and Environmental Science (JBES), 5(1), 470-475.

Haider, H. \& Ali, W. (2011). Fecal Coliform Management Using a Coupled Hydrodynamics and Water Quality Model for the River Ravi in Pakistan. Pakistan Journal Engineering and Applied Science, 9, 48-57.

Indarsih, W., Suprayogi, S. \& Widyastuti, M. (2011). Kajian Kualitas Air Sungai Bedog Akibat Pembuangan Limbah Cair Sentra Industri Batik Desa Wijirejo. Majalah Geografi Indonesia, 25(1), 40-54.

Kalaivani, T.R., Dheenadayalan, M.S. \& Sivakumar, K.K. (2014). Microbial Status in River Coom Pollution, Chennai, India. Journal of Science, 4(2), 113-116.

Kementrian Kesehatan Republik Indonesia. (2011). Situasi Diare di Indonesia. Buletin (Online) (http:// www.depkes.go.id/folder/view/01/structurepublikasi-pusdatin-buletin.html di akses 9 Januari 2016)
Khotimah, S. (2013). Kepadatan Bakteri Coliform di Sungai Kapuas Kota Pontianak. Prosiding Semirata. Bandar Lampung: Fakultas Matematika dan Ilmu Pengetahuan Alam Universitas Lampung.

Notoatmodjo, S. (2007). Kesehatan Masyarakat Ilmu dan Seni. Jakarta: Rineka Cipta.

Onwumere, G. (2007). Willapa River Fecal Coliform Bacteria Verification Study. Water Quality Monitoring Report. Environmental Assessment Program. Washington State Department of Ecology Olympia, Washington. available on the Department of Ecology's website (www.ecy. wa.gov/biblio/0703039.html)

Peraturan Pemerintah Nomor 38 Tahun 2011, tentang Sungai.

Peraturan Gubernur Kalimantan Selatan Nomor 5 Tahun 2007, tentang Peruntukan dan Baku Mutu Air Sungai.

Prayitno, A. (2009). Uji Bakteriologi Air Baku dan Siap Konsumsi dari PDAM Surakarta Ditinjau dari Jumlah Bakteri Coliform. Skripsi. Surakarta: Universitas Muhammadiyah Surakarta. (Online) (http://eprints.ums.ac.id/3821/1/A420040040.pdf diakses 3 Oktober 2015).

Sumantri, A. (2013). Kesehatan Lingkungan. Jakarta: PT. Fajar Interpratama Mandiri.

Sanders, E.C., Yuan, Y. \& Pitchford, A. (2013). Fecal Coliform and E. coli Concentrations in EffluentDominated Streams of the Upper Santa Cruz Watershed. Water, 5, 243-261.

Shoolikhah, I., Purnama, Ig.S. \& Suprayogi, S. (2014). Kajian Kualitas Air Sungai Code Propinsi Daerah Istimewa Yogyakarta. Majalah Geografi Indonesia, 28(1), 23-32.

Water and Sanitation Program. (2009). Informasi Pilihan Jamban Sehat. (Online) (http://www. stbmindonesia.org/files/Katalog\%20Opsi\%20 Jamban\%20Sehat.pdf diakses 1 Februari 2016) 